IJTC

Ilomata International Journal of Tax \& Accounting

P-ISSN: 2714-9838; E-ISSN: 2714-9846

Vol. 1 No. 4 October 2020 pp.185-192

https://www.ilomata.org/index.php/iitc

\title{
Competitive Performance Is Affected By A Competitive Strategy With Supply Chain Moderates
}

\author{
Herlin Rosalina Febriyanti ${ }^{1}$, Elva Nuraina ${ }^{2}$, Nur Wahyuning Sulistyowati ${ }^{3}$ \\ ${ }^{123}$ PGRI Madiun University \\ Correspondent: nurwahyu@,unipma.ac.id
}

Submitted : September 20,2020 Revised : October 10, $2020 \quad$ Published $\quad$ : October 31, 2020

\begin{abstract}
This study aims to examine the effect of competitive strategies on company performance with supply chains as moderating. This type of research is quantitative research. The sampling technique was purposive sampling. Data analysis techniques used simple linear regression and subgroups using Moderated Regression Analysis. The results of the study show that competitive strategies have an effect on company performance. Supply chain as a moderating variable strengthens the relationship of competitive strategies to company performance. Low cost strategies and differentiation are used in measuring competitive strategies. Where differentiation strategies are more applied than low cost strategies due to the object of research in the fields of property, real estate, building construction that produces limited and unique products at high costs.
\end{abstract}

Keywords: Competitive Strategy; Supply Chain; Company Performance

\section{INTRODUCTION}

Success in the economic sector is one of the indicators he says of an independent and prosperous society. Along with the development of the globalization era and the development of industry in the 21 st century, it demands an increasingly fierce business competition. The success of a competition is seen from the company's performance. The ideal company performance generates a growing profit. The Indonesia Stock Exchange noted that up to November 1, 2018 there were $87 \%$ of companies with a total of 519 companies that had reported their third quarter 2018 financial statements. Total assets increased by Rp. 510 trillion, namely an increase of $6 \%$ from the previous year. The end of 2017 amounted to Rp 9,177 trillion to Rp 9,687 trillion in the third quarter of 2018. The highest increase in assets was by the Mining, Miscellaneous Industry, and Property, Real Estate and Building Construction sectors. Net profit increased by $12 \%$ or Rp. 26 trillion. The third quarter of 2017 amounted to Rp 218 trillion to Rp 244 in the third quarter of 2018. Increase in the percentage of net profit by the Basic Industry and Chemical, Miscellaneous Industry, and Property, Real Estate and Building Construction sectors (Bursa Efek Indonesia, 2018). The Indonesia Stock Exchange recorded increased performance in the Property, Real Estate and Building Construction sectors. Shares in this sector have grown to $7.37 \%$ year to date. Several issuers who have penetrated the target market include PT PP Properti Tbk, which is targeting marketing sales of around 3.8 trillion in 2019. As for the realization of the sales target sudah didapatkan oleh PT PP Properti Tbk pada tahun 2018 sebesar Rp 3,4 triliun (Anonim, 2019). Head of Primary Division of the Fiscal Policy Agency (BKF) Asep Nurwanda said that the construction sector and the real estate sector are expected to continue to grow steadily in line with the progress of building investment and the sustainability of infrastructure provision and public housing 
programs. Revenues from the property sector increased by 6.9\% from 2017 to 2018. Taxes received by the state originating from this sector can be realized up to IDR 83.51 trillion per period 31 December 2018. In 2019 the government will continue to be committed to supporting the housing program through the state budget of IDR 10.39 trillion (Rama, 2019).

Philosophical assumptions underlie the stewardship theory which explains that humans can basically be trusted, their behavior is full of responsibility, have integrity, and are always honest with other parties (Kholid \& Bachtiar, 2014). Managers are motivated to have their attitudes and behaviors reflected collectively for the benefit of the organization so that the main characteristic in this theory is cooperation between all components in the organization. This theory design is useful for testing the situation, executives in the company as stewards which are usually done by managers to be motivated to take actions according to the wishes of the principal in order to achieve organizational goals Donaldson \& Davis (in Suhartati \& Rosietta, 2012). An increase in company assets and profits will reflect an increase in company performance. Performance can be assessed both financially and non-financially. Performance is a description of how much the achievement of a policy or activity plan is achieved in the process of realizing the targets, aspirations, vision and mission of the organization in the form of a structured plan directed by an organization. Performance indicators from a financial perspective are the level of sales growth, profit level, return on capital employed, and level of investment use (Moeheriono, 2012). Company performance can be calculated using Tobin's Q ratio. Tobin's $Q$ value comes from the total value of the stock market and compares the market value of debt with the total value of capital related to production activities Tobin (in Sudiyatno \& Puspitasari, 2010).

The success of achieving a performance cannot be separated from the implementation of a company's strategy. Strategy is a tool that is useful in the process of achieving the ideals of an entity where these ideals are related to the formulation of long-term goals, planned follow-up programs, and priority placement of each resource, the resources in question include non-human components as well as humans (Fitriadi, Soekarto, \& Sunarti, 2013). The size of the suitability of a strategy determines the success or failure of a strategy that has been made (Slamet, Nainggolan, Ramdani, Hendriyanto, \& Ilma, 2016). There are two generic competitive strategies, namely cost advantage and differentiation. Cost advantage can be achieved by implementing cost reduction, while differentiation in achieving profit is the means of providing increased service levels Porter (in Ritonga, 2018). The success of a competitive strategy cannot be separated from the interference of the business network or what is often known as supply chain management. Supply chain management is the coordination of all supply chain activities, starting from the procurement of raw materials until the product is received by the customer and the customer is satisfied. The implementation of supply chain management uses a set of methods to streamline the functions of suppliers, manufacturers, warehouses, distributors, wholesalers or retailers, as well as logistics activities so that the resulting products can be distributed in an accurate total, the right location according to target achievement, on time without delay so that Minimizing the value of the load and customer service satisfaction is fulfilled Simchi-levi (in Rahmasari, 2008; Heizer and Render (in Ilmiyati \& Munawaroh, 2016). There are ways to measure activities in supply chain management that can apply a combination of SCOR and ROA performance measurement models, including company wealth, cost, time, reliability, capacity, responsiveness, productivity, flexibility Sidarto (in Hanugrani, Setyanto, \& Efranto, 2013).

Competitive strategy with indicators of low cost strategies affects company performance and competitive strategies with indicators of differentiation strategies have an effect on company 
performance (Fadlilah, 2013). Competitive strategy has a significant positive effect on company performance with indicators of low cost strategies and differentiation strategies, in line with Ulfa (2015) arguing that the role of supply chain management is able to strengthen the relationship of competitive strategy with company performance. Previous research examined manufacturing companies listed on the IDX, while the novelty in this study was aimed at property, real estate, and building construction companies which aimed to examine the effect of competitive strategy on company performance, test whether the supply chain was able to strengthen the relationship between the two. This study also aims to determine whether the results will be the same as previous studies even though the types of products produced are different due to different research objectives.

The theoretical uses of research include: 1) Providing scientific contributions that are useful in understanding company management starting from competitive strategies, supply chain, and company performance, 2) Can describe the effect of competitive strategy on company performance that is influenced by supply chain. 3) As a reference for comparing and developing future research in the field of financial management. While the practical uses of research include: 1) The author can implement the knowledge gained during the lecture period, 2) Companies can source additional information about competitive strategies and supply chain in making decisions, improve or plan for better company performance, 3) Results This research can be used as a reference for investors in making investment decisions, namely the competitive strategy used by the company can have an impact on improving company performance, 4) Adding a university reference collection for academics regarding the effect of competitive strategies on financial performance with the supply chain as a moderating variable.

\section{METHODS}

This research is a quantitative research with secondary data sources in the form of annual financial reports audited by the company and published by the official website of the Indonesia Stock Exchange and the official website of property, real estate, and building construction companies. The population in this study was 58 with a total sample of 32 property, real estate, and building construction companies listed on the Indonesia Stock Exchange (BEI) in the 2015-2017 period. This study uses nonrandom sampling because not all elements of the population have the same criteria. While the sample was taken based on the purposive sampling method because in determining the sample the researcher considered and based on the criteria set by the researcher. The data analysis technique used is descriptive statistical analysis, simple linear regression analysis and the Moderate Regression Analysis (MRA) test to determine the results of moderation.

The calculation of a competitive low cost proxy strategy analysis uses asset utilization efficiency, namely the ratio of total sales revenues to total assets. The analysis of competitive differentiation proxy strategy calculation using price premium capability, namely the ratio of gross margin compared to total sales revenues (Gani \& Jermias, 2006).

\section{Asset Utilization Efficiency $=\underline{\text { Total Sales Revenues }}$ \\ Total Asset \\ Price Premium Capability $=$ Gross Margin \\ Total Sales Revenues}

The calculation of supply chain is based on a combination of the two financial ratios, namely the measure of cash generation and asset efficiency. First, calculating the cash generation ratio by comparing cash inflows from the entity's operating activities with sales. Second, the calculation of 
Competitive Performance Is Affected By A Competitive Strategy With Supply Chain Moderates Febriyanti, Nuraina, \& Sulistyowati

the asset efficiency ratio by comparing sales to total assets minus debt Christopher (in Suhartati \& Rosietta, 2012).

Supply Chain $=\underline{\text { Cash Flow from Operation }}$ Total Asset - Current Liabilities

Meanwhile, the calculation of company performance uses Tobin's Q ratio, which is the ratio of the market value of the entity's shares compared to the book value or the acquisition value of the entity's equity Tobin, Jose et al. (in Ulfa, 2015).

$\mathrm{KP}=\underline{(\text { Closing Price } \times \text { Total Outstanding Common Shares })+(\text { Total Payable }+ \text { Stock }- \text { Current assets })}$

Total Company Assets

RESULTS AND DISCUSSION

Table 1. Simple Linear Regression Test

\begin{tabular}{|c|c|c|c|c|c|c|}
\hline \multicolumn{7}{|c|}{ Coefficients $^{a}$} \\
\hline \multirow{2}{*}{\multicolumn{2}{|c|}{ Model }} & \multicolumn{2}{|c|}{$\begin{array}{l}\text { Unstandardized } \\
\text { Coefficients }\end{array}$} & \multirow{2}{*}{$\begin{array}{c}\text { Standardized } \\
\text { Coefficients } \\
\text { Beta }\end{array}$} & \multirow[t]{2}{*}{$\mathrm{T}$} & \multirow[t]{2}{*}{ Sig. } \\
\hline & & B & Std. Error & & & \\
\hline 1 & (Constant) & 010 & 004 & & 2,523 & 013 \\
\hline \multicolumn{7}{|c|}{ a. Dependent Variable: KP } \\
\hline \multicolumn{7}{|c|}{$\begin{array}{l}\text { Source: Results of data processing of SPSS version } 24 \text { (2019) } \\
\text { Table 2. Simple Linear Regression Test }\end{array}$} \\
\hline \multicolumn{7}{|c|}{ Coefficients $^{a}$} \\
\hline \multirow{2}{*}{\multicolumn{2}{|c|}{ Model }} & \multicolumn{2}{|c|}{$\begin{array}{l}\text { Unstandardized } \\
\text { Coefficients }\end{array}$} & $\begin{array}{c}\text { Standardized } \\
\text { Coefficients }\end{array}$ & $\mathrm{T}$ & Sig. \\
\hline & & $\mathrm{B}$ & Std. Error & Beta & & \\
\hline 1 & (Constant) & ,000 & ,000 & & 1,525 & 131 \\
\hline & SK_PPC & ,993 & ,004 & ,999 & 223,194 & ,000 \\
\hline
\end{tabular}

Source: Results of data processing of SPSS version 24 (2019)

Based on Table 1. the results of hypothesis testing indicate that competitive strategy has a positive effect on company performance. The test results are in accordance with the results of the proposed research hypothesis. Competitive strategy t-test with low cost proxy (SK_AUE) shows t count $>$ t table $(13,783>1,661)$ and a Sig value of $0,000(0,000<0.05)$. This means that competitive strategies with low cost proxies have an effect on company performance.

Meanwhile, based on Table 2. the results of the $\mathrm{t}$ test for competitive strategy with differentiation proxies (SK_PPC) show $t$ count $>t$ table $(223,194>1,661)$ and a Sig value of 0,000 $(0,000<0.05)$. This means that competitive strategies with differentiation proxies have an effect on company performance.

The competitive strategy of a company can be measured using a low cost indicator that is calculated or formulated using asset utilization efficiency. When implementing a competitive strategy with a low cost strategy indicator, it will directly have an impact on improving company performance. This identifies its importance in the efficiency of the company's operational activities. The less expenses incurred to fulfill operational activities; the less utilization of company assets is used. The impact of the minimal use of company assets is an increase in company performance (Ulfa, 2015).

Low cost applications are usually carried out by large-scale businesses that promote standard products or services with relatively small differentiation and are acceptable to most buyers. In addition, companies usually provide discounts to customers in order to maximize sales and 
increase market share (Sarwono, 2011). A low cost competitive strategy (cost leadership) seeks to improve efficiency and cost control throughout the organization's supply chain. Low costs can be minimized through the economies of scale approach to production, studying the effect of curves, tight cost control, and minimizing costs in areas, for example research and development, services, sales or advertising Porter (in Aji, 2015).

Competitive strategy with differentiation indicators using price premium capability measurement. The use of differentiation shows that the company can impose a price premium on its customers. The charging of prices is carried out through techniques of using strategies that innovate their products and provide attractive services (Ulfa, 2015). Organizations have been successful in differentiating their products through improved quality functions, both more reliable after-sales service and delivery and through improved functionality Porter (in Aji, 2015). When customers feel satisfaction with the quality provided by the company, the customer will pay loyal with a special price (price premium). In addition, with the existence of a differentiation strategy, customers or consumers will indirectly provide a good image assessor to the entity, the impact on the brand's popularity followed by increased sales, this will improve company performance. The characteristics of organizations that operate using a competitive strategy with differentiation indicate that the organization has an above average profit margin due to being unique in the market and will continually update its products or services to meet customer needs (Aji, 2015).

The findings in this study are the application of low cost strategies or competition for cost control carried out by several companies, including the company Duta Pertiwi Tbk using a marketing strategy through a price lock program by giving discounts to customers when making Down Payment purchases. In addition, there is a price amnesty program, namely the availability of discounts to customers. Products from Duta Pertiwi Tbk include landed houses, shop houses and offices, industrial estates, commercial lands, and apartments. Some companies that use a low cost strategy by optimizing operational costs but combined with a differentiation strategy, namely the company PT Nusa Raya Cipta Tbk, PP (Persero) Tbk, Wijaya Karya Tbk.

Meanwhile, the research findings of several companies that use differentiation strategies are more than those of low cost strategies. Property, real estate, and building construction companies usually use a differentiation strategy in terms of improving customer service and innovating the uniqueness of the resulting product. Some companies that use a differentiation strategy include companies: Alam Sutera Realty Tbk, Bekasi Fajar Industrial Estate Tbk, Bhuwanatala Indah Permai Tbk, Bumi Serpong Damai Tbk, Cowell Development Tbk, Ciputra Development Tbk, Duta Anggada Realty Tbk, Nusa Kontruksi Enjiniring Tbk, Intiland Development Tbk, Nirvana Development Tbk, Indonesia Prima Property Tbk, Plaza Indonesia Realty Tbk, PP (Persero) Tbk, Danayasa Arthatama Tbk, Total Bangun Persada Tbk, Wijaya Karya Tbk. 
Competitive Performance Is Affected By A Competitive Strategy With Supply Chain Moderates Febriyanti, Nuraina, \& Sulistyowati

Table 3. Moderate Regression Analysis Test

\begin{tabular}{|c|c|c|c|c|c|c|}
\hline \multicolumn{7}{|c|}{ Coefficients $^{a}$} \\
\hline \multirow{2}{*}{\multicolumn{2}{|c|}{ Model }} & \multicolumn{2}{|c|}{$\begin{array}{l}\text { Unstandardized } \\
\text { Coefficients }\end{array}$} & $\begin{array}{l}\text { Standardized } \\
\text { Coefficients }\end{array}$ & $\mathrm{T}$ & Sig. \\
\hline & & B & Std. Error & Beta & & \\
\hline \multirow[t]{4}{*}{1} & (Constant) & ,008 & ,007 & & 1,121 & ,267 \\
\hline & SK_AUE & 1,087 & 188 & 1,185 & 5,782 & ,000 \\
\hline & SC & ,038 & 127 & ,028 & 299 & ,766 \\
\hline & INTERACTION1 & 103 & ,051 & 418 & 2,030 & ,047 \\
\hline & Ident Variable: KP & & & & & \\
\hline
\end{tabular}

Source: Results of data processing of SPSS version 24 (2019)

Tabel 4. Uji Analisis Regresi Moderat

\begin{tabular}{|c|c|c|c|c|c|c|}
\hline \multicolumn{7}{|c|}{ Coefficients ${ }^{a}$} \\
\hline \multirow{2}{*}{\multicolumn{2}{|c|}{ Model }} & \multicolumn{2}{|c|}{$\begin{array}{l}\text { Unstandardized } \\
\text { Coefficients }\end{array}$} & \multirow{2}{*}{$\begin{array}{c}\text { Standardized } \\
\text { Coefficients } \\
\text { Beta }\end{array}$} & \multirow[t]{2}{*}{$\mathrm{T}$} & \multirow[t]{2}{*}{ Sig. } \\
\hline & & B & Std. Error & & & \\
\hline \multirow[t]{4}{*}{1} & (Constant) &,- 001 & ,002 & &,- 432 & 667 \\
\hline & SK_PPC & ,889 & ,042 & 904 & 20,998 & ,000 \\
\hline & SC & ,048 & ,027 & ,035 & 1,788 & ,079 \\
\hline & INTERACTION2 &,- 028 & ,013 &,- 090 & $-2,157$ & ,035 \\
\hline & ndent Variable: KP & & & & & \\
\hline
\end{tabular}

Source: Results of data processing of SPSS version 24 (2019)

Based on the results of hypothesis testing with the MRA model in Table 3. and Table 4. It shows that the supply chain can strengthen the effect of competitive strategy on company performance is indicated by a significance value $<0.05$. That is, the moderating variable can strengthen the relationship between $\mathrm{X}$ and $\mathrm{Y}$ variables. The results of the interaction relationship in Table 3 are shown from the significant value of the interaction between the competitive strategy variable with low cost proxies and the supply chain at a sig value of $0.047(0.047<0.05)$. Whereas in Table 4. the significance value of the interaction relationship between the competitive strategy variable and the proxies for differentiation and supply chain is a sig value of $0.035(0.035<0.05)$. This means that in this case it can be concluded that the supply chain strengthens the influence of competitive strategies on company performance.

The implementation of the correct supply chain management according to the supply chain management concept will contribute to the impact of increasing competitive advantage in terms of its products and in the supply chain system implemented by the entity. The entity must prove that the implementation of the supply chain is able to drive the entity's competitive strategy Heyzer and Render (in Ulfa, 2015). Supply chain illustrates that an approach whose use aims to achieve efficient integration of several parties, for example suppliers, distributors, manufacturers, retailers, logistics, and customers. The existence of a supply chain has an impact on cost control and a rapid increase in service quality. Supply chain management can be used as a set of tools for the creation of a competitive strategy in implementing better company performance growth than before. Qi, Zhao, \& Sheu (2011) suggest that supply chain strategies can be used to support the implementation of competitive strategies.

The implication of supply chain management has three objectives, namely costs can decrease according to the limits set by the entity, decrease the use of capital, renew and improve services to buyers. Achieving cost reductions by minimizing logistics costs, for example in the selection of transportation and warehousing tools and models with the lowest prices. Minimizing the level of investment in logistics will have an effect on reducing capital. Service improvement activities are 
jointly carried out actively in order to have an influence on the company's profitability and revenue Anatan and Ellitan (in Suhartati \& Rosietta, 2012).

The test results between the interaction of supply chain variables and competitive strategies with low cost proxies and differentiation are proven to have an effect on strengthening the relationship to company performance. So it can be concluded that the sample companies that implement supply chain management in an effort to focus in terms of fulfilling buyer demand on the lowest price. The total costs incurred are minimized using supply chain relationships with other parties and good product and service innovation strategies. This implementation will have an impact on the creation of a good competitive strategy and the realization of an increase in company performance.

Research findings in the implementation of supply chain management, almost all property, real estate, and building construction companies implement it, namely through cooperative relationships with other parties, for example with BUMN, BUMD, foreign parties, raw material providers, advertising media marketing parties, event organizers, banking parties, and companies in other sectors.

\section{CONCLUSION}

The results of research and discussion indicate that competitive strategy has a positive effect on company performance. A competitive strategy with two proxies of low cost and differentiation has an effect on financial performance. Supply chain strengthens the influence of competitive strategy on company performance. This means that the supply chain variable is a moderating variable. The findings in this study are that some companies use more differentiation strategies because the products of companies engaged in this sector produce products with a selling value of tens of millions so that the costs incurred in the product manufacturing process are very large. In addition, the products produced have characteristics and uniqueness that cannot be separated from the imposition of premium prices on buyers. The implementation of supply chain management involves many parties, both internal and external, starting from the processing of the supply of raw materials until the product is ready to be purchased. The limitation in this study is that not all of the companies' financial statements in the researched sector describe the account closing price and the number of ordinary shares outstanding. In addition, there were several companies in the 2015 - 2017 period that did not publish their financial reports either on the IDX website or on the company's official website. So this will affect the number of research samples. It is hoped that the next research, when using secondary data, can conduct research on more than one sector of the company and increase the period of years in the study.

\section{REFERENCES}

Aji, P. (2015). Manajemen strategi Keunggulan bersaing berkelanjutan. Yogyakarta: Ekuilibria.

Anonim. (2019). Analis menilai kenaikan saham properti di awal 2019 disebabkan sudah undervalued. Diambil 2 Januari 2019, dari https://investasi.kontan.co.id/news/analismenilai-kenaikan-saham-properti-di-awal-2019-disebabkan-sudah-undervalued.

Bursa Efek Indonesia. (2018). 78 persen perusahaan tercatat raih laba bersih pada kuartal III 2018. Access on Januari 2, 2019, dari https://idx.co.id?berita/press-releasedetail/?emitenCode $=994$. 
Competitive Performance Is Affected By A Competitive Strategy With Supply Chain Moderates Febriyanti, Nuraina, \& Sulistyowati

Fadlilah, N. (2013). Pengaruh strategi kompetitif terhadap kinerja perusahaan dengan supply chain sebagai variabel moderating (studi pada perusahaan manufaktur yang terdaftar di BEI tahun 2008-2011). Perbanas Institutional Repository, 1-12.

Fitriadi, B., Soekarto, \& Sunarti. (2013). Strategi bersaing: suatu kajian perumusan strategi pemasaran guna meraih keunggulan kompetitif (studi pada pt. ongkowidjojo, malang). Jurnal Administrasi Bisnis, 5(1), 1-11.

Gani, L., \& Jermias, J. (2006). Investigating the effect of board independence on performance across different strategies. The International Journal of Accounting, 41, 295-314.

Hanugrani, N., Setyanto, N. W., \& Efranto, R. Y. (2013). Pengukuran performansi supply chain dengan menggunakan supply chain operation reference (scor) berbasis analytical hierarchy process (ahp) dan objective matrix (omax). Jurnal Rekayasa dan Manajemen Sistem Industri, 1(1), 163-172.

Ilmiyati, A., \& Munawaroh, M. (2016). Pengaruh manajemen rantai pasokan terhadap keunggulan kompetitif dan kinerja perusahaan ( studi pada usaha kecil dan menengah di kabupaten bantul ). Jurnal Manajemen Bisnis, 7(2), 226-251.

Kholid, M. N., \& Bachtiar, A. (2014). Pengaruh dana syirkah temporer dan good corporate governance terhadap kinerja maqasid syariah bank syariah di indonesia. Universitas Islam Indonesia, (4), 1-25.

Moeheriono. (2012). Pengukuran kinerja berbasis kompetensi. Jakarta: Rajawali Pers.

Qi, Y., Zhao, X., \& Sheu, C. (2011). The impact of competitive strategy and supply chain strategy on business performance : the role of environmental uncertainty. 42(2), 371-389.

Rahmasari, L. (2008). Pengaruh supply chain management terhadap kinerja perusahaan dan keunggulan bersaing (studi kasus pada industri kreatif di provinsi jawa tengah). Majalah Ilmiah INFORMATIKA, 2(3), 89-103.

Rama, H. (2019). Perkembangan infrastruktur dongkrak pertumbuhan properti. Diambil 2 Januari 2019, dari http://wartakota.tribunnews.com/2019/01/24/perkembangan-infrastrukturdongkrak-pertumbuhan-properti-2019? page $=2$.

Ritonga, Z. (2018). pengaruh strategi bersaing dan orientasi wirausaha terhadap kinerja perusahaan dengan lingkungan persaingan sebagai variabel moderator (studi pada perusahaan jasa laundry di labuhanbatu). ECOBISMA (Jurnal Ekonomi, Bisnis dan Manajemen), 5(2), 107 119.

Sarwono, J. (2011). Marketing intelligence. Yogyakarta: Graha Ilmu.

Slamet, R., Nainggolan, B., Ramdani, H., Hendriyanto, A., \& Ilma, L. lu'ul. (2016). Strategi pengembangan ukm digital dalam menghadapi era pasar bebas. Jurnal Manajemen Indonesia, 16(2), 136-147.

Sudiyatno, B., \& Puspitasari, E. (2010). Tobin's q dan altman z-score sebagai indikator pengukuran kinerja perusahaan. Kajian Akuntansi, 2(1), 9-21.

Suhartati, T., \& Rosietta, H. (2012). Pengaruh strategi bersaing terhadap hubungan antara supply chain management dan kinerja (studi pada perusahaan manufaktur yang terdaftar di bei). Simposium Nasional Akuntansi XV, 1-42.

Ulfa, M. (2015). Pengaruh strategi bersaing dengan supply chain management sebagai variabel moderating pada perusahaan manufaktur di bursa efek indonesi. Perbanas Institutional Repository, 1-18. 